\title{
INŻYNIERIA KONSTYTUCYJNA W POKOMUNISTYCZNYCH PRZEMIANACH USTROJOWYCH*
}

\section{WPROWADZENIE}

Tematem artykułu sa pokomunistyczne przemiany ustrojowe z lat 1989$1991 \mathrm{w}$ byłym bloku sowieckim badane z perspektywy wyborów konstytucyjnych, tj. procesu tworzenia podstaw ładu politycznego. Podstawa analizy jest „inżynieria konstytucyjna” rozwijana na gruncie podejścia instytucjonalnego w politologii oraz ekonomii politycznej konstytucji ${ }^{1}$. Termin „inżynieria konstytucyjna" upowszechnił Giovanni Sartori². Dotyczy on tworzenia wiążących metanorm, tj. ogólnych zasad określających kształt państwa i regulujących tworzenie praw niższego rzędu ${ }^{3}$. Sa to „[...] procedury zapewniające kontrolowane sprawowanie władzy"4. Reszta, zauważa Enrico Colombatto, to puste zwroty ${ }^{5}$. U podstaw politycznej ekonomii konstytucji leży rozróżnienie między dwiema płaszczyznami analitycznymi, z jednej strony tworzeniem reguł gry (konstytucja), z drugiej - gra zgodnie z tymi regułami. Pierwsza płaszczyzna jest narzędziem inżynierii konstytucyjnej. Ekonomia polityczna traktuje zaś rynek i państwo jako odmienne sfery instytucjonalne, w ramach których

\footnotetext{
* Wcześniejsza wersja tego artykułu została przedstawiona w ISP PAN na seminarium na temat neoinstytucjonalizmu. Autorzy pragną wyrazić wdzięczność Piotrowi Chmielewskiemu, Kai Gadowskiej, Henrykowi Szlajferowi za szczegółowe uwagi krytyczne i sugestie. Podziękowania należą się także Ireneuszowi Sadowskiemu oraz innym uczestnikom dyskusji na wspomnianym seminarium.

1 J. M. Buchanan, The constitution of economic policy, „The American Economic Review” 77(3), 1987, s. 243-250; idem, The domain of constitutional economics, „Constitutional Political Economy" 1(1), 1990; idem, G. Tullock, The Calculus of Consent: Logical Foundations of a Constitutional Democracy, Univ. of Michigan Press, Ann Arbor 1965.

${ }^{2}$ G. Sartori, Comparative Constitutional Engineering: An Inquiry into Structures, Incentives, and Outcomes, New York Univ. Press, New York 1994. Sartori konkluduje: „systemy konstytucyjne, zarówno przeszłe, jak i współczesne, sa [...] faktycznie systemami liberalnymi. Ktoś mógłby powiedzieć, że politykę liberalną stanowi konstytucjonalizm - konstytucjonalizm szukający rozwiązania politycznej wolności w dynamicznym podejściu do prawnej koncepcji wolności” (idem, Teoria demokracji, tłum. P. Amsterdamski, D. Grinberg, WN PWN, Warszawa 1994, s. 379). 1982.

${ }^{3}$ E. Ostrom (ed.), Strategies of Political Inquiry, Sage Publications, Beverly Hills-London

${ }^{4}$ G. Sartori, Comparative Constitutional Engineering..., s. 202.

${ }^{5}$ E. Colombatto, It was the rule of law, „Revue Economique” 2007, January, s. 1174.
} 
ludzie realizują wzajemne korzyści wynikające ze swobodnej wymiany i współpracy. Właściwości tych aren określają konstytuujące je reguły gry ${ }^{6}$.

Konstytucje nie są neutralne z punktu widzenia jednostkowych i grupowych interesów - nie tylko regulują zdolność jednostek i grup do ich realizacji, lecz także kształtują ich treść. Tworząc porządek społeczny, pisał Thomas Hobbes, człowiek jest zarówno podmiotem, jak i przedmiotem działania. Konstytucje sa nie tylko efektem obiektywnego zamysłu, ale też i produktem gry sprzecznych interesów, paktem zawierającym reguły, do których przestrzegania strony formalnie się zobowiązały. Trwałość kompromisu, czyli stabilność konstytucyjnych metareguł, zależy od uznania ich słuszności: od ich ugruntowania $\mathrm{w}$ podzielanych przez społeczeństwo normach i wartościach ${ }^{7}$, wiary w ich bezstronność - konstytucje uprzywilejowujące interesy jednej strony obowiąują dopóty, dopóki trwa jej dominacja ${ }^{8}$.

Treść aktu konstytucyjnego nie określa ściśle efektów ustrojowych. Według Maurice'a Duvergera ${ }^{9}$ Konstytucja Finlandii zapewnia prezydentowi szersze kompetencje niż Konstytucja Francji - w praktyce jest odwrotnie. Zawarty w Konstytucji USA projekt ustroju odbiega od tego, który wyłonił się w rezultacie historycznych okoliczności i uzusów ${ }^{10}$. Projektanci ustroju działają w warunkach ograniczonej wiedzy, a zatem nie są w stanie przewidzieć wszystkich konsekwencji swych wyborów ${ }^{11}$. Dotyczy to nie tylko skutków konkretnych wyborów konstytucyjnych, lecz także ich konstelacji.

W debatach ustrojowych i racjonalizacji aktów konstytucyjnych nieunikniony jest element normatywny, tj. idea „dobrego państwa”, „dobrych instytucji”. Jak pisał John S. Mill: „Rząd sądzić należy wedle jego wpływu na bieg rzeczy, wedle tego, co robi z obywateli i co robi z nimi, wedle jego dążności do poprawy lub zepsucia ludzi samych. I wedle dobroci lub wadliwości dzieł, których dokonywał dla nich lub z nimi"12. Podobnie konstytucjonalna ekonomia polityczna widzi w państwie przedsięwzięcie na rzecz realizacji dobra zbiorowości: instytucje demokratycznego państwa należy „[...] badać i porównywać z punktu widzenia sposobu, w jaki umożliwiają obywatelom osiaganie wzajemnych korzyści oraz chronią ich przed eksploatacja, w drodze procesu politycznego, ze strony innych obywateli bądź aktorów politycznych"13.

Przemiany ustrojowe, jakie zaszły w czasie rozpadu komunizmu w byłym bloku sowieckim w latach 1989-1992, znalazły wyraz w nowych konstytu-

${ }^{6}$ V. J. Vanberg, Market and state: the perspective of constitutional political economy, „Freiburg Discussion Papers on Constitutional Economics” 2010, No. 04/10.

${ }^{7}$ F. A. von Hayek, The Constitution of Liberty, The Univ. of Chicago Press, Chicago 1978, s. 181

${ }^{8}$ A. Przeworski, Democracy and the Market. Political and Economic Reforms in Eastern Europe and Latin America, Cambridge Univ. Press, New York 1991, s. 36.

${ }_{9}$ M. Duverger, A new political system model: semi-presidential government, „European Journal of Political Research" 8(2), 1980.

${ }^{10}$ F. A. von Hayek, op. cit., s. 184.

11 A. Przeworski, op. cit., s. 35.

12 J. S. Mill, O rzqdzie reprezentatywnym i Poddaństwo kobiet, tłum. G. Czernicki, Znak i Fundacja Stefana Batorego, Kraków-Warszawa 1995, s. 68.

${ }^{13}$ V. J. Vanberg, op. cit., s. 21. 
cjach $^{14}$. Ich wpływ na rzeczywiste funkcjonowanie systemów politycznych był zróżnicowany: jedne państwa przyjęły ustroje autorytarne ${ }^{15}$, inne ewoluowały w kierunku konstytucyjnego liberalizmu ${ }^{16}$. Niektóre instytucje typowe dla demokracji formalnie występowały w systemie totalitarnym (parlament, sądy) jako byty iluzoryczne. Zmiana ustrojowa przebiegła tu w sytuacji słabości instytucjonalnej: instytucje komunistyczne były w rozpadzie, a ich personel szukał „tratw ratunkowych”; z kolei nowe instytucje ustrojowe były słabe lub tylko w projekcie. Znamienne, że w żadnym kraju pokomunistycznym nie było głębszej refleksji nad pożądanym kształtem ustroju. Wybory konstytucyjne pozostawały przedmiotem gabinetowych przetargów między grupami interesów. Twórcy konstytucji zdawali się zakładać, że ich zadanie polega na transplantacji istniejących gdzie indziej rozwiązań ${ }^{17}$. Postępowanie analityczne ustapiło miejsca metodzie politycznej ${ }^{18}$.

Konstrukcja artykułu jest następująca: opis i ocena skutków wyborów ustrojowych stanowi przedmiot części drugiej artykułu. Część trzecia dotyczy podstaw konstytucyjnego liberalizmu z naciskiem na rolę społeczeństwa obywatelskiego i elit władzy w kształtowaniu porządku politycznego, tj. na suwerenność polityczną obywateli. Hipotezy badawcze są weryfikowane w części czwartej, poświęconej analizie porównawczej przekształceń ustrojowych na obszarze posowieckim. Część piąta zawiera najważniejsze wnioski z analizy powstawania nowych porządków politycznych w krajach byłego bloku sowieckiego.

\section{WYBORY KONSTYTUUJĄCE PORZĄDEK POLITYCZNY: MENU USTROJOWYCH ROZSTRZYGNIĘĆ}

Celowe projektowanie instytucji politycznych nie jest przedsięwzięciem nowym $^{19}$. Dopiero jednak okres oświecenia przyniósł wiarę w możliwość świadomego projektowania ustrojów państw. Pierwszym tego efektem była Konstytucja Stanów Zjednoczonych Ameryki; potem - Konstytucja 3 maja. Zamiarem przyświecającym twórcom Konstytucji USA była budowa „dobrego państwa” i w pewnym stopniu rzutował on na inne konstytucje, choć ustroje europejskie odbiegały znacząco od wzoru amerykańskiego.

W trzech sprawach panuje zgoda. Po pierwsze, podstawa systemu konstytucyjnego jest zasada trójpodziału władz - wykonawczej, ustawodawczej i są-

${ }^{14}$ K. Metelska-Szaniawska, Constitutions and economic reforms in transition: an empirical study, „Constitutional Political Economy” 20(1), 2008, s. 1-41.

15 F. Zakaria, The rise of illiberal democracy, „Foreign Affairs” 76(6), 1997.

${ }^{16} \mathrm{Na}$ temat pojęcia konstytucyjnego liberalizmu zob. G. Sartori, Teoria demokracji.

${ }_{17}$ P. Winczorek, Dobre państwo - spojrzenie prawnika, w: W. Kieżun, J. Kubin (red.), Dobre państwo, Wyd. WSPiZ, Warszawa 2004, s. 27.

18 J. March, H. Simon, Organizations, John Wiley and Sons, Inc., New York 1958.

${ }^{19} \mathrm{Na}$ przykład Harold Berman uznał stworzony w XI w. przez Grzegorza VII system prawa kanonicznego za akt konstytucyjny we współczesnym rozumieniu (idem, Law and Revolution: The Formation of the Western Legal Tradition, Harvard Univ. Press, Cambridge, MA, 1983. 
downiczej. Po drugie, to ustroje liberalno-demokratyczne doprowadziły w ciągu ostatnich dwóch wieków do bezprecedensowego rozwoju gospodarczego i redukcji ubóstwa. Zawdzięcza się to mocnym podstawom, jakich dostarczyły konstytucje ochronie praw własności, wolności gospodarczej, egzekwowania umów oraz swobód politycznych. Trzecia kwestia dotyczy pola podstawowych rozstrzygnięć ustrojowych: typu rządów, metod wyboru reprezentacji politycznej przez obywateli oraz hierarchiczności organizacji państwa.

\section{Typy rządów}

Debatę o typach rządów sprowokował Juan Linz krytyką rządów prezydenckich, jako niestabilnych i łatwo przechodzących w dyktatury ${ }^{20}$. Prezydenci niechętnie przyjmuja rygor kadencyjnych ograniczeń sprawowanej władzy, co prowadzi do łamania konstytucji i dyktatury. Sprzyja temu poczucie przewagi nad parlamentem z tytułu wyboru w głosowaniu powszechnym. Do narzucenia dyktatury moga wykorzystać struktury siłowe i administrację państwa. Ryzyko dla stabilności państwa powstaje też, gdy prezydent jest z innej partii politycznej niż ta, która dominuje w parlamencie. Grozi to paraliżem rządu i prowokuje do zamachu stanu. Respektowanie zobowiązań podjętych przez prezydentów w trakcie kampanii wyborczych powoduje sztywność rządów prezydenckich. Przywódcy rządów parlamentarnych zawierają sojusze w trakcie rządzenia, co zapewnia elastyczność działań. Przytoczone dane empiryczne potwierdzają większą stabilność demokracji w warunkach rządów parlamentarnych.

Argumenty Juana Linza i Alfreda Stepana mają nierówną wagę. Podstawa ich uogólnień są dane dotyczące Ameryki Płd. Niektórzy krytycy zauważyli²1, że niestabilność rządów prezydenckich pojawia się, gdy towarzyszy im ordynacja proporcjonalna w wyborach do parlamentu. Kombinacja rządów prezydenckich i ordynacji proporcjonalnej sprzyja korupcji ${ }^{22}$. Realizacja uprzednio zawartych zobowiązań wyborczych świadczy o większej przejrzystości tej formy rządu. Dodajmy, że system prezydencki pozwala jasno rozdzielić władzę ustawodawcza, wykonawczą i sądowniczą w państwie, tj. wprowadzić przejrzysty mechanizm kontroli i równowagi. W warunkach, kiedy rząd wyłania parlament, władza wykonawcza i ustawodawcza silnie się ze sobą wiążą, co może ograniczyć niezależność władzy sądowniczej.

${ }^{20}$ J. Linz, The perils of presidentialism, „Journal of Democracy” 1(1), 1990; idem, A. Stepan, Problems of Democratic Transition and Consolidation: Southern Europe, South America, and Postcommunist Europe, Johns Hopkins Univ. Press, Baltimore-London 1996.

${ }^{21}$ S. Mainwaring, Presidentialism in Latin America, w: A. Lijphart (ed.), Parliamentary versus Presidential Government, Oxford Univ. Press, Oxford-New York 1992, s. 114; M. S. Shuggart, J. M. Carey, Presidents and Assemblies. Constitutional Design and Electoral Dynamics, Cambridge Univ. Press, Cambridge 1992.

${ }_{22}$ T. Persson, G. Tabellini, F. Trebbi, Electoral rules and corruption, Discussion Paper Series, No. 2741, Center for Economic Policy Research, London 2001; J. Kunicova, S. Ross-Ackerman, Electoral systems and constitutional structures as constraints on corruption, „British Journal of Political Science” 35(4), 2005. 
Ostatecznie, stabilność rządów prezydenckich zależy od siły pozostałych organów państwa, gotowości respektowania przez ich personel porządku konstytucyjnego oraz żywotności instytucji społeczeństwa obywatelskiego. W takich warunkach podjęcie przez prezydenta próby pogwałcenia konstytucji i obalenia demokracji wiąże się z poważnym, osobistym ryzykiem. Nie wchodząc głębiej $\mathrm{w}$ tę tematykę, dodajmy, że przy innych czynnikach stałych, łatwiej jest zbudować stabilne, demokratyczne państwo z rządem parlamentarnym niż z prezydenckim ${ }^{23}$.

$\mathrm{Na}$ koniec, cechą wyróżniającą rządów półprezydenckich jest zbliżenie się do prezydencjalizmu, gdy osoba prezydenta oraz większość w parlamencie należą do tej samej partii, a do parlamentaryzmu w sytuacji przeciwnej ${ }^{24}$. Oscylacje te nie prowadzą jednak do rządów w pełni prezydenckich czy w pełni parlamentarnych, co uzasadnia oddzielne ich traktowanie.

\section{Rodzaje systemów wyborczych}

Ordynacja wyborcza wpływa: na strukturę wewnętrzną partii politycznych i ich liczbę, rekrutację ludzi do polityki, na relacje między rządzącymi a rządzonymi. O wpływie ordynacji wyborczych na liczbę partii politycznych mówi prawo Duvergera ${ }^{25}$. Zgodnie z nim w systemie większościowym liczba partii zmierza do dwóch. W systemie dwupartyjnym jedna z partii sprawuje rząd, podczas gdy druga jest w opozycji. Z WOW-ami (wielomandatowe okręgi wyborcze) wiążą się systemy wielopartyjne i rządy koalicyjne. Czynnikiem stabilizującym WOW-y jest „dążenie do mediany”. „Obie partie wybierające swój program na osi lewica-prawica mają motywację do zbliżenia się do wyborcy zajmującego pozycję medianową na tej osi, czyli takiego, że przynajmniej połowa wyborców jest równie lub bardziej radykalna jak on i przynajmniej połowa jest równie lub mniej radykalna jak on"26.

Debatę między zwolennikami JOW-ów (jednomandatowe okręgi wyborcze) i WOW-ów rozpoczął u progu lat dziewięćdziesiątych Arend Lijphart²7, zalecając krajom pokomunistycznym przyjęcie WOW-ów, jako sprawiedliwszych i dajacych lepszą reprezentację mniejszości. Jego oponenci wytknęli szereg, w ich mniemaniu, słabości WOW-ów: trudność sformowania rządu, słabą rozliczalność polityków, dezintegrujący wpływ tej ordynacji na społe-

\footnotetext{
${ }^{23}$ Łatwość nie oznacza koniecznie wyższości parlamentaryzmu nad systemem prezydenckim. Np. autorzy znanego empirycznego studium ekonomicznych efektów ustrojów konstytucyjnych (T. Persson, G. Tabellini, The Economic Effects of Constitutions, MIT Press, Cambridge, MA, 2003), wykazują wyższość tego ostatniego. Wnikliwą ocenę wyników badan empirycznych ekonomii konstytucji przedstawił Stefan Voigt (Empirical constitutional economics: onward and upward?, „Journal of Economic Behavior \& Organization” 80(2), 2011, s. 319-330; idem, Positive constitutional economics II - a survey of recent developments, „Public Choice” 146(1-2), 2011, s. 205-256).

${ }^{24}$ G. Sartori, Comparative constitutional engineering..., s. 121-140.

${ }_{25}$ M. Duverger, Political Parties: Their Organization and Activity in the Modern State, Methuen, London 1954.

${ }^{26}$ M. Kamiński, Metody głosowania w okręgach jednomandatowych i ich wtasności, „Decyzje” 2015, nr 23 (czerwiec), s. 11-12.

${ }^{27}$ A. Lijphart, Constitutional choices for new democracies, „Journal of Democracy” 1991, Winter; idem, Double-checking the evidence, „Journal of Democracy” 1991, Summer.
} 
czeństwo itp. ${ }^{28}$ Lijphart początkowo ustapił, stwierdzając, że ordynacja proporcjonalna jest lepsza pod wymienionymi wyżej względami, ale pewną jej słabością jest rozliczalnośćc ${ }^{29}$. Trzy lata później ${ }^{30}$ wyraził pogląd, że WOW-y zapewniają większą sprawność ekonomiczna. Tezę tę zakwestionował Liam Anderson ${ }^{31}$, wykazujacc, że gdy uwzględni się korporatyzm i autonomię banku centralnego, zależność między ordynacją proporcjonalna a sprawnościa eko-

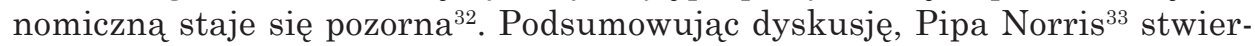
dziła, że wybór między jedną a drugą metodą wyboru reprezentacji zależy od preferencji: czy wyżej stawia się odpowiedzialność i skuteczność rządów, czy też reprezentację mniejszości i sprawiedliwość społeczną.

W systemie większościowym wyborcy, dając większość parlamentarną jednej z partii, wybierają rząd, który zobowiązany jest to realizacji programu wyborczego. Negocjacje wokół programu rządu toczą się poza parlamentem - w społeczeństwie obywatelskim. W systemie proporcjonalnym - koalicja formuje się w parlamencie, gdzie dopiero uzgadniany jest program rządu. Jednym słowem, w systemie większościowym suwerenem są obywatele - wyborcy, w proporcjonalnym - politycy w parlamencie.

Inaczej też w każdym z systemów wygląda wyłanianie kandydatów na posłów. W systemie JOW-ów partia wystawia osoby, które mają szansę zwyciężyć w danym okręgu i liczy się z nimi, jako tymi, którzy mają lokalne poparcie. W systemie proporcjonalnym, nawet przy otwartych listach, wyborcy głosuja na partię, a kandydaci zawdzięczają miejsce na liście jej kierownictwu, a zatem wektor zależności jest wychylony w kierunku przywódców partii, kosztem wpływu obywateli. Ogranicza to zdolność elektoratu do rozliczenia swych przedstawicieli i w pewnych warunkach może stać się fikcyjną.

Badania porównawcze pozwalają stwierdzić inne różnice. Torsten Persson i Guido Tabellini ${ }^{34}$ uważaja, że rządy parlamentarne z ordynacja proporcjonalna, w porównaniu z systemem większościowym, są bardziej kosztowne w utrzymaniu. Z kolei według Torbena Iversena i Davida Soskice’a ${ }^{35}$ JOW-y

${ }_{28}$ G. Laydeyret, The problem with $P R$, i Q. L. Quade, PR and democratic statecraft, w: L. Diamond, M. W. Plattner (eds.), The Global Resurgance of Democracy, The Hopkins Univ. Press, Baltimore 1993.

${ }^{29}$ A. Lijphart, Electoral Systems and Party Systems: A Study of Twenty-Seven Democracies, 1945-1990, Oxford Univ. Press, Oxford-New York 1994, s. 144.

${ }^{30}$ A. Lijphart, Reflections - dimensions of democracy, „European Journal of Political Research" 31, 1997.

${ }^{31}$ L. Anderson, The implications of institutional design for macroeconomic performance: reassessing the claims of consensus democracy, „Comparative Political Studies” 34(4), 2001.

${ }^{32}$ Anderson następująco podsumował wyniki swych badań: „w świecie idealnym najbardziej właściwą konstelacją instytucjonalną dla osiagnięcia optymalnych warunków do optymalnych wyników makroekonomicznych okazała się większościowa ordynacja wyborcza, z korporacyjnym systemem godzenia interesów oraz niezależnym bankiem centralnym" (idem, op. cit., s. 448-449). Według innych autorów również finanse publiczne są w lepszej kondycji w systemie JOW-ów (T. Persson, G. Tabellini, op. cit., cytowani przez S. Voighta, Empirical constitutional...).

${ }^{33}$ P. Norris, Choosing electoral systems: proportional, majoritarian and mixed systems, „International Political Science Review” 18(3), 1997, s. 301.

${ }^{34}$ T. Persson, G. Tabellini, op. cit.

${ }_{35}$ T. Iversen, D. Soskice, Electoral Institutions and the politics of coalitions: why some democracies redistribute more than others, „American Political Science Review” 100, 2006, s. 165-181; zob. S. Voigt, Empirical constitutional..., passim. 
sprzyjaja raczej przewadze partii centroprawicowych, a WOW-y - centrolewicowych.

Statystycznie istotne wyniki badań porównawczych nad ustrojami politycznymi są często na dość niskim poziomie korelacji ${ }^{36}$. Nie zaskakuje to, gdyż efekt systemu wyborczego zależy od wielu czynników środowiskowych, jak poziom kultury społeczeństwa obywatelskiego, typ rządu, stopień centralizacji decyzji, ustrój administracyjny itd. W sumie chodzi o stan innych instytucji wspomagających rozliczalność pionową i poziomą.

\section{Rządy federalne i unitarne}

Podział władzy w pionie hierarchii państwa zawiera się na kontinuum między pełna centralizacją a pełną decentralizacją kompetencji. Słowo kontinuum może budzić zastrzeżenia, gdyż między ustrojem powstałym w drodze oddolnej integracji autonomicznych jednostek a budowanym odgórnie przez suwerenne decyzje władzy centralnej występuje różnica jakościowa ${ }^{37}$.

Ustrój federacyjny posiada swoistą dynamikę. Jest on polem gry między dążeniem części składowych do poszerzenia kompetencji a podobnymi zamiarami centrum. Obie tendencje muszą podlegać kontroli; w innym przypadku system przesunie się w kierunku unitarnym lub - rozpadu. Należy więc rozróżniać między strukturą i procesem federalnym, gdyż nawet w warunkach formalnych rozwiązań federacyjnych może wyłonić się potężne, wszechwładne centrum $^{38}$. Równowaga między władzami w ramach hierarchii państwa występuje, gdy „federacja jest wspólnotą złożoną z silnych elementów składowych i silnego rządu centralnego, z których każdy posiada władzę oddelegowaną mu przez lud i upoważnioną do zwracania się (deal with) bezpośrednio do społeczności obywateli w wykonywaniu tych uprawnień"39.

Dawno już spostrzeżono uboczne, korzystne dla jakości demokracji, efekty federalizmu. Lord Acton zauważył, że federalizm znacząco wzmacnia działający w poziomie mechanizm kontroli i równowagi przez dodanie wymiaru pionowego $^{40}$. Autonomia jednostek organizacyjnych w ramach tego systemu pozwala osiagnąc „ekonomię skali”. Jest to możliwe, jeśli żaden szczebel rządu nie

\footnotetext{
${ }^{36} \mathrm{Na}$ przykład Jana Kunicova i Susan Rose-Ackerman (op. cit.) stwierdziły, że systemy $\mathrm{z}$ ordynacja proporcjonalna są bardziej wystawione na korupcję i poszukiwanie renty politycznej niż te z ordynacją większościowa. Przyczyny tego upatruja w ograniczonej zdolności elektoratu do rozliczania rządów. Podobne wyniki uzyskali T. Persson, G. Tabellini, F. Trebbi, op. cit.

${ }^{37}$ Nie wyklucza to możliwości ewolucji absolutyzmów monarszych w kierunku ustroju konstytucjonalnego (zob. P. Kaczorowski, Państwo w czasach demokracji, ISP PAN, Warszawa 2005, s. 163-198).

${ }^{38}$ Zdaniem niektórych autorów w USA od II wojny światowej występuje trend ku nadmiernej centralizacji (V. Ostrom, The Meaning of American Federalism: Constituting a Self-Governing Society, Institute of Contemporary Studies, San Francisco 1991; M. R. Levin, The Liberty Amendments. Restoring the American Republic, Threshold Editions, New York 2013; D. J. Elazar, Explaining Federalism, Alabama Univ. Press, Tuscaloosa-London 1987, s. 67-69).

${ }^{39}$ D. J. Elazar, op. cit., s. 7.

${ }^{40}$ Lord J. Acton, Essays in the History of Liberty, ed. by J. Rufus Fears, Liberty Fund, Indianapolis 1985, s. 211.
} 
zdominuje pozostałych ${ }^{41}$. Mechanizm kontroli i równowagi działa więc tu nie tylko w wymiarze poziomym, ale i w pionowym, wymuszając rozliczalność poszczególnych rządów i organów państwa. Jak stwierdza Larry Diamond: „Jedynie wtedy, gdy uprawnienia polityczne, obejmujące pewne sprawy i funkcje rządowe, sa przekazane na niższe, demokratycznie wybrane szczeble władzy, rząd może być rzeczywiście odpowiedzialny (responsive), przedstawicielski i rozliczalny"42.

John S. Mill podkreślał wpływ federalizmu na poziom obywatelskiej świadomości. Wiązał sukces ustroju demokratycznego z oświata, zdolnością obywateli do pojęcia idei interesu ogólnego i ich wolą zgodnego z nim działania. Jedno i drugie jednostka może nabyć tylko wtedy, gdy pełni funkcje publiczne, co umożliwia decentralizacja rządów i praktyka samorządu. Rząd centralny może się wówczas skupić na celach priorytetowych, bezpieczeństwa i rozwoju kraju, pozostawiając resztę samorządom różnych szczebli hierarchii państwa ${ }^{43}$.

\section{DYGRESJA: DETERMINANTY USTROJU KONSTYTUCYJNEGO LIBERALIZMU}

Twierdzimy, że o efekcie końcowym transformacji w kierunku ustroju konstytucyjnego liberalizmu przesądzaja postawa elit i stan społeczeństwa obywatelskiego ${ }^{44}$. Elitę polityczna stanowią jednostki lub grupy zajmujące pozycje władzy w społeczeństwie, wpływające bezpośrednio na treść kluczowych decyzji politycznych. W chwili przełomu ustrojowego do niej należy podjęcie decyzji rozstrzygających o kształcie państwa. Nie są one dowolne - podejmując je, elita bierze pod uwagę możliwe reakcje społeczeństwa: im słabiej jest ono zintegrowane, tym większa swoboda dla arbitralnych decyzji; przeciwnie, im społeczeństwo jest mocniej zintegrowane, tym bardziej klasa polityczna musi brać pod uwagę jego reakcje.

Miarą stanu społeczeństwa jest suwerenność obywateli: w ekonomii konstytucjonalnej odpowiada jej suwerenność konsumenta. Suwerenność obywatelska „wymaga [...] takiego zaprojektowania instytucji i procedur decyzyjnych,

${ }^{41}$ V. Ostrom, The Political Theory of a Compound Republic: Designing the American Experiment, $2^{\text {nd }}$ ed. revised and enlarged, Univ. of Nebraska Press, Lincoln-London 1987, s. 137; Ch. Lindblom, The Intelligence of Democracy: Decision-making through Mutual Adjustment, Free Press, New York 1965.

${ }^{42}$ L. Diamond, Developing Democracy: Toward Consolidation, The Johns Hopkins Univ. Press, Baltimore-London 1999, s. 159.

${ }^{43}$ J. S. Mill, O rzqdzie..., s. 85-86; idem, Zasady ekonomii politycznej, t. 2, tłum. E. Tylor, PWN, Warszawa 1966, s. 785-786; A. Brady, Introduction, w: The Collected Works of John Stuart Mill: Essays on Politics and Society, vol. 18, ed. by J. M. Robson, Univ. of Toronto Press, TorontoBuffalo 1977, s. XL.

${ }^{44}$ Ze względu na brak miejsca nie zajmiemy się tu treścią pojęcia „społeczeństwo obywatelskie”. Świetny przegląd różnych znaczeń i koncepcji tego pojęcia zawiera artykuł Jerzego Szackiego (Wstep. Powrót idei społeczeństwa obywatelskiego, w: Ani ksiaże, ani kupiec: obywatel, Znak i Fundacja im. Stefana Batorego, Kraków-Warszawa 1997). Zob. też I. Słodkowska, Społeczeństwo obywatelskie na tle historycznego przełomu: Polska 1980-1989, ISP PAN, Warszawa 2006, s. 44-74). 
by proces polityczny maksymalizował wspólny interes obywateli” ${ }^{45}$. Z normatywnego punktu widzenia rola elit polega więc na wprowadzaniu i utrzymywaniu reguł konstytucyjnych zapewniających suwerenność obywatelska. Nie jest jasne, kiedy elity godzą się na poświęcenie interesów partykularnych na rzecz interesu ogólnego ${ }^{46}$.

Postawy elity i stan społeczeństwa są wartościami współzależnymi; na dłuższą metę jakość przywództwa zależy od poziomu rozwoju kultury politycznej - zapotrzebowania na suwerenność obywatelską. Gdy go brak, wówczas wdrożenie reguł, które maksymalizuja suwerenność obywatelska, powinno należeć do zadań przywództwa politycznego. Sugeruje to celowość rozdzielnego traktowania tych kategorii: elita polityczna może w danej chwili lepiej lub gorzej wywiązywać się ze swoich funkcji wobec społeczeństwa obywatelskiego. Jak pokażemy w dalszym ciąu artykułu, to właśnie relacja między jakością elity politycznej a stanem społeczeństwa określa faktyczną treść podstawowych wyborów ustrojowych.

Znaczenie elit w tworzeniu systemu polityczno-gospodarczego podją Henryk Szlajfer ${ }^{47}$. Rozróżnił on nacjonalizm holistyczny i partykularystyczny: „[...] w zależności od wariantu, nacjonalizm koncentruje się albo na maksymalizacji partykularnych korzyści (nacjonalizm partykularystyczny), albo na osiaganiu - w kompleksowych interakcjach między państwem a aktorami społecznymi pewnego zbioru dóbr publicznych, określonych jako interes publiczny, włączając w to potrzebę wzrostu gospodarczego i wzmocnienia gospodarki narodowej (nacjonalizm holistyczny)”48. Jego zdaniem „typem idealnym” nacjonalizmu holistycznego jest podejście do państwa i gospodarki Maxa Webera. Nacjonalizm partykularystyczny redukuje interes ogólny do poziomu interesów sektorowych ${ }^{49}$. Rozróżnienie to odpowiada dwóm, przyjętym przez nas, alternatywnym typom systemu wartości elit politycznych (tab. 1).

Tabela 1

System wartości narodowej elity a poziom rozliczalności poziomej i pionowej

\begin{tabular}{|l|l|l|l|}
\cline { 3 - 4 } \multicolumn{2}{|c|}{} & \multicolumn{1}{c|}{$\begin{array}{c}\text { System wartości elity politycznej - } \\
\text { przywództwo }\end{array}$} \\
\cline { 3 - 4 } \multicolumn{2}{l|}{} & $\begin{array}{l}\text { Dominacja } \\
\text { interesów } \\
\text { partykularnych }\end{array}$ & $\begin{array}{l}\text { Uniwersalizm } \\
\text { interesów: interes } \\
\text { publiczny }\end{array}$ \\
\hline \multirow{2}{*}{$\begin{array}{l}\text { Rozliczalność - suwerenność } \\
\text { polityczna obywatela }\end{array}$} & Niska & I (stagnacja) & $\begin{array}{l}\text { II (względna stabilność } \\
\text { i wzrost) }\end{array}$ \\
\cline { 3 - 4 } & Wysoka & $\begin{array}{l}\text { III (niestabilna } \\
\text { równowaga) }\end{array}$ & $\begin{array}{l}\text { IV (stabilność } \\
\text { i zamoźność) }\end{array}$ \\
\hline
\end{tabular}

${ }^{45}$ V. J. Vanberg, op. cit., s. 21.

${ }^{46}$ B. Ackerman, Constitutional economics/constitutional politics, Faculty Scholarship Series. Paper 134, 1999, http://digitalcommons.law.yale.edu/fss_papers/124.

${ }^{47}$ H. Szlajfer, Economic Nationalism and Globalization: Lessons from Latin America and Central Europe, Brill, Leiden-Boston 2012, s. 91-99.

${ }^{48}$ Ibidem, s. 91.

49 Ibidem, s. 93-94. 
Każde z pól przedstawia inny zakres politycznych i ekonomicznych szans. Pole I łączy niską rozliczalność z partykularyzmem elity, co skutkuje wysokim poziomem korupcji i stagnacja gospodarcza. Pole II cechuje słabe formalne instytucje rozliczania urzędników publicznych i wysoki poziom zorientowania elity na sukces kolektywny - dążenie do narodowej chwały, prestiżu itp. Pole III zawiera niestabilny układ równowagi, co prowadzi do przejęcia przez partie polityczne kontroli nad państwem (P I) lub, dzięki skutecznemu oporowi, wspieranych przez społeczeństwo obywatelskie instytucji ustrojowych, do narzucenia dyscypliny interesom partykularnym (P IV). Pole IV obejmuje warunki korzystne dla konstytucyjnego liberalizmu: przewaga wartości uniwersalnych, żywe społeczeństwo obywatelskie i silne instytucje zapewniają stabilność oraz sprzężenia zwrotne pobudzające rozwój polityczno-gospodarczy ${ }^{50}$.

Dla pokomunistycznej zmiany ustroju istotna jest przestrzeń między polami I i II: niska rozliczalność czyni motywację elit zmienną kluczową. Przyjmujemy, że w postawie pokomunistycznych elit wobec zmian ustrojowych przeważały interesy partykularne, zmienną zewnętrzną (lub egzogeniczna) była siła społeczeństwa obywatelskiego. Efekt końcowy przemian ustrojowych zależał więc od stanu społeczeństwa obywatelskiego: jego zdolności do ograniczenia dążenia elity politycznej do utrwalenia pozycji władzy i przywileju. Zajmiemy się tym w dalszej części artykułu.

Zakładamy, że w pewnych warunkach elita polityczna może wznieść się ponad swój partykularny interes i działać dla dobra publicznego ${ }^{51}$. Kiedy może pojawić się owa republikańska postawa elity? Sprzyjają temu dwie sytuacje: zewnętrzne zagrożenie dla bytu państwa lub wewnętrzne zagrożenie ze strony aktywnego społeczeństwa obywatelskiego. Obie zagrażaja jej istnieniu, co uzasadnia poszukiwanie poparcia społecznego. Nie wykluczamy też możliwości wystapienia w etosie elity idei republikańskich, skłaniających do służby wartościom szerszym niż wąsko pojęty interes własny. Postawy te wystapia raczej w środowiskach o tradycjach historycznych niż u elity o świeżej proweniencji ${ }^{52}$. Na zachowanie elity wpływ ma też zapewne zależność jej pozycji materialnej i społecznej od państwa: im bardziej interesy te zależą od powiązań z aparatem państwa, tym mniej będzie skłonna myśleć w kategoriach publicznych.

Stan społeczeństwa obywatelskiego zależy od złożonych uwarunkowań historycznych. Ustrój polityczny może rozwijać zdolności samoorganizacyjne w społeczeństwie lub je aktywnie niszczyć; kultura narodu może sprzy-

${ }^{50}$ R. D. Putnam, Demokracja w działaniu. Tradycje obywatelskie we wspótczesnych Włoszech, współpr. R. Leonardi, R. Y. Nanetti, tłum. J. Szacki, Znak, Fundacja S. Batorego, Kraków-Warszawa 1995, s. 247 i 276-277; A. Z. Kamiński, B. Kamiński, Korupcja rzqdów: państwa pokomunistyczne wobec globalizacji, ISP PAN i Wyd. TRIO, Warszawa 2004, s. 265-268; D. Acemoglu, J. A. Robinson, Dlaczego narody przegrywaja?, tłum. J. Łoziński, Wyd. Zysk i S-ka, Poznań 2014.

${ }^{51}$ Dopuszczał to też Karol Marks (Przyczynki do historii kwestii polskiej. Rękopisy z lat 18631864, tłum. Z. Bogucki, KiW, Warszawa 1986, s. 153), wskazując na Konstytucję 3 maja (por. B. Ackerman, Constitutional economics...).

${ }^{52}$ G. Mosca, The Ruling Class. Elementi di Scienza Politica, McGrow-Hill Book Company, New York-Toronto-London 1938, s. 144; A. de Tocqueville, Dawny ustrój i rewolucja, tłum. A. Wolska, Czytelnik, Warszawa 1970, s. 166. 
jać międzygrupowemu współdziałaniu, budując więzi zaufania i umożliwiając uniwersalizację wartości ${ }^{53}$. Stabilizacja ustroju komunistycznego wymagała zniszczenia w społeczeństwie zdolności do współdziałania. Dobrze funkcjonujący ład konstytucyjno-liberalny wymaga zaś jej wysokiego poziomu. Ważnym elementem zdolności do współdziałania, esencji społeczeństwa obywatelskiego jest patriotyzm - poczucie narodowej tożsamości. Wpływa on na gotowość do poświęcenia bieżących interesów partykularnych na rzecz długofalowego interesu zbiorowości ${ }^{54}$.

Zdolność obywateli do rozliczania rządów wymaga spełnienia określonych warunków instytucjonalnych: wolności prasy i stowarzyszeń, demokratycznych wyborów, sprawnego i niezależnego sądownictwa. Z kolei kultura społeczeństwa, za pośrednictwem socjalizacji zawodowej, wpływa na działanie instytucji ustrojowych. Od tego zależy działanie całości mechanizmu kontroli i równowagi na poziomie państwa. Relacja między elitą polityczną a społeczeństwem jest więc złożona i wpływa bezpośrednio na treść konstytucji i jej wpływ na sprawowanie rządów.

Gry wokół rozstrzygnięć ustrojowych nie ograniczają się do tworzenia konstytucji, lecz trwają w procesie implementacji jej zasad. Uczestniczą w niej kręgi elity politycznej, aktorzy zewnętrzni - państwa i instytucje międzynarodowe oraz organizacje i stowarzyszenia pozarządowe. Postanowienia konstytucji podlegają różnorakim interpretacjom. Poza podstawowymi wyborami ustrojowymi, liczą się ich kombinacje. Każdy ustrój państwa stanowi unikatowy przypadek, to zaś, co sprawdza się w jednych okolicznościach, w innych może dać opaczny wynik. Biorąc pod uwagę te zastrzeżenia, projektowanie konstytucji jest aktem publicznym, który decyduje na długie lata o prawomocności ustroju, sprawności państwa i rozwoju społeczno-gospodarczym.

Dotychczasowe rozważania pozwalają na sformułowanie czterech hipotez (tab. 1), które spróbujemy zweryfikować w następnej części artykułu:

1. Kombinacja partykularystycznej elity i słabego, niezdolnego do obywatelskiego współdziałania społeczeństwa prowadzi do autorytarnych rozwiązań ustrojowych.

2. Kombinacja względnie silnego społeczeństwa obywatelskiego i partykularystycznej elity prowadzi do kompromisu ustrojowego ograniczającego zdolność społeczeństwa do rozliczania rządzących, z zachowaniem pozorów skonsolidowanej demokracji.

3. Kombinacja holistycznej elity i słabego społeczeństwa obywatelskiego prowadzi do wyborów ustrojowych i polityki sprzyjajacych rozwojowi intelektualno-moralnemu społeczeństwa.

4. Kombinacja holistycznej elity i silnego społeczeństwa obywatelskiego teoretycznie prowadzi do wyborów optymalnych - w odniesieniu do krajów pokomunistycznych jest to jednak zbiór pusty.

53 R. Putnam, op. cit.

${ }^{54}$ E. Shills, The Virtue of Civility. Selected Essays on Liberalism, Tradition, and Civil Society, ed. by S. Grosby, Liberty Fund., Indianapolis 1997. 


\section{POKRĘTNA DROGA POKOMUNISTYCZNYCH PRZEMIAN USTROJOWYCH}

Reżim komunistyczny jest niekonstytucyjny i antyliberalny. Zniesienie własności prywatnej i rynku, instytucji reprezentatywnych i niezależnego sadownictwa oznaczało ubezwłasnowolnienie społeczeństwa oraz fizyczne i materialne zniszczenie jego elit. Rewolucja komunistyczna usunęła tym samym wszystkie mechanizmy poziomej i pionowej rozliczalności rządów. W konsekwencji nadzór nad transformacją ustrojową sprawowali „nowi ludzie”, często jako sojusz części antykomunistycznej opozycji z elementami establishmentu komunistycznego. Pokomunistyczne przejścia ustrojowe różni od poprzednich fal demokratyzacji głębia i zakres zmian w ustroju polityczno-gospodarczym.

W analizie trajektorii zmian ustrojowych przyjmiemy wstępnie model złożony z dwu elementów: społeczeństwa (S) i establishmentu komunistycznego (EK). EK obejmuje osoby zajmujace wysokie polityczne i administracyjne stanowiska partyjne i państwowe - tj. dodatnią stronę panowania ${ }^{55}$. S przedstawia negatywną stronę panowania. Jego stan określa kontinuum między atomizacją a ułomnym w tych warunkach społeczeństwem obywatelskim. Środowisko EK łączy nadrzędny interes w przetrwaniu systemu. Wymaga to pełnienia skutecznej kontroli politycznej nad S oraz stopy wzrostu gospodarki niezbędnej, by zaspokoić potrzeby aparatu państwa. Słabość kontroli prowadzi do wyłonienia się w łonie $\mathrm{S}$ względnie zorganizowanej opozycji $(\mathrm{O})$.

Oba cele - kontrola polityczna oraz wzrost gospodarczy - były po osiagnięciu pewnego etapu rozwoju nie do pogodzenia. Z punktu widzenia wymogów kontroli im bardziej zuniformizowane i zatomizowane $\mathrm{S}$ oraz im bardziej zdyscyplinowany EK, tym większa stabilność polityczna komunistycznego państwa. Z drugiej strony rozwój gospodarczy wymaga tolerancji dla różnorodności interesów i opinii, która system destabilizuje. W sytuacji gdy EK jest podzielony przez wewnętrzne konflikty, możliwe są trzy sytuacje: (1) napięcia moga prowadzić do rozkładu systemu, gdy jedna z grup w EK odwołuje się do społecznego poparcia (Węgry 1956, Czechosłowacja 1968); (2) w społeczeństwie może pojawić się nieformalna, quasi-zintegrowana O (Polska 19761989) lub w innym przypadku - grupka dysydentów. Warunkiem przetrwania $\mathrm{O}$ jest poparcie $\mathrm{S}$ i słabość EK. Istnienie $\mathrm{O}$ wprowadza do systemu politycznego element rozliczalności. Wzajemne relacje między elementami triady S-EK-O określą kierunek i radykalizm pokomunistycznej transformacji.

Za Scottem Mainwaringiem ${ }^{56}$ rozważymy trzy typy przejścia ustrojowego: (1) przez ugodę (transaction); (2) obalenie ustroju (regime defeat); (3) wymanewrowanie (extrication). Każda z tych trzech sytuacji może zajść w układzie EK-O-S ${ }^{57}$. W pierwszym przypadku układ znajduje się w stanie względnej równowagi, co czyni wynik bezpośredniej konfrontacji wysoce niepewnym: ugoda między stronami pozwala jej uniknąć. W drugim przypadku O przeważa nad EK

${ }^{55}$ R. Dahrendorf, Class Conflict in an Industrial Society, Routledge \& Kegan Paul, London 1959, s. 213-218.

${ }^{56}$ S. Mainwaring, op. cit., s. 323.

${ }^{57}$ Podobną typologię scenariuszy zmiany ustrojowej zaproponował Samuel Huntington (idem, Trzecia fala demokratyzacji, tłum. A. Dziurdzik, WN PWN, Warszawa 1995, s. 220-223). 
i samodzielnie decyduje o sposobie przeprowadzenia zmian. W trzecim - EK kontroluje S (O nie występuje) i wyznacza korzystną dla siebie trajektorię zmiany.

Kluczowa jest relacja między EK i S: silne S implikuje słabość EK; a silne $\mathrm{S}$ wytwarza O. Warunki korzystne do wyłonienia O występują w społeczeństwach zakorzenionych w kulturze zachodnioeuropejskiej, o wyraźnym poczuciu tożsamości narodowej, tj. o potencjalnie silnym S. Sa ku temu dwa powody: ich system wartości nie sprzyja stabilizacji ustroju komunistycznego - utrata suwerenności wzbudza w nich opór. W sytuacji pokomunistycznej zmiany ustroju będą one bardziej skłonne zaakceptować materialne wyrzeczenia narzucone programem głębokich reform gospodarczych.

Transformacje pokomunistyczne przedstawiają inny obraz niż druga i trzecia fala demokratyzacji ${ }^{58}$. Reżim komunistyczny był „systemem światowym”, złożonym z państw politycznie i gospodarczo podporządkowanych ZSRR. W trakcie powojennej historii bloku komunistycznego mechanizmy kontroli ZSRR nad państwami satelickimi ulegały ewolucji przez formalizację i rozluźnienie, w pewnych granicach, bezpośredniej zależności polityki wewnętrznej tych państw ${ }^{59}$. Przekroczenie tych granic w wyniku walk wewnętrznych w EK lub naporu S groziło upadkiem reżimu w danym kraju, co uprawdopodobniało epidemię i wymagało przeciwdziałania metropoliii ${ }^{60}$. Przywódcy państw satelickich dążyli do rozszerzenia pola samodzielności w stosunku do metropolii, lecz zarazem $\mathrm{w}$ ich interesie było zachowanie bloku jako całości. W obliczu destabilizacji ustrojowej każda ze stron w negocjacjach - EK, S czy O - musiała w swych kalkulacjach uwzględnić groźbę zewnętrznej interwencji wojskowej. Dotyczyło to szczególnie trzech „opornych” społeczeństw: Czechosłowacji, Polski i Węgier ${ }^{61}$.

Wróćmy do charakterystyki trzech wyróżnionych tu trajektorii transformacji ustrojowej: dwie z nich to trajektorie demokratyczne (TD1, TD2), trzecia prowadzi do ustroju autorytarnego (TA). Z każdą z nich wiąże się inny układ wyborów konstytucyjnych:

TD1 - mocne S z quasi-zinstytucjonalizowanym O i zewnętrznie zróżnicowanym EK; wysoki poziom niepewności co do zamiarów Kremla. Mogło to skłonić zagrożonych przywódców kraju satelickiego do zidentyfikowania i wzmocnienia tych elementów w O, które chcieliby mieć jako ewentualnych partnerów w rozmowach. Bierność Kremla umożliwiała negocjowaną zmianę

\footnotetext{
58 Ibidem.

${ }_{59}$ Pojęcia kontroli, epidemii i zgodności interesów wprowadził do analizy międzynarodowego systemu komunistycznego Luarence Whitehead, Democracy and decolonization: East-Central Europe, w: idem (ed.), The International Dimensions of Democratization: Europe and the Americas, Oxford Univ. Press, Oxford-New York 1996, s. 524. A. Z. Kamiński, An Institutional Theory of Communist Regimes: Design, Function, and Breakdown, ICS Press, San Francisco 1992).

60 Wydarzenia w Polsce i na Węgrzech w połowie 1956 r. wzajemnie na siebie oddziaływały, prowadząc do eskalacji antykomunistycznego buntu. Interwencja zbrojna ZSRR na Węrzech informowała Polaków, że osiągnęli granice tolerancji Kremla. Interwencja wojsk Paktu Warszawskiego w Czechosłowacji w 1968 r. dała okazję do ogłoszenia doktryny Breżniewa, która upoważniała Moskwę do zbrojnej interwencji, gdy trwałość ustroju komunistycznego w państwie satelickim była zagrożona.

${ }^{61}$ Każde z tych społeczeństw inaczej reagowało na sytuację podporządkowania (A. Kamiński, Coercion, corruption, and reform: state and society in the soviet-type socialist regime, „Journal of Theoretical Politics” 1(1), 1989; idem, An Institutional Theory..., passim).
} 
ustroju (pacted transition) ${ }^{62}$. W wyniku uzgodnień partia komunistyczna przekształca się w socjaldemokrację, włączając się w proces demokratyzacji. Jest to przypadek „kooperatywnej zmiany ustroju” (Polska i Węgry) ${ }^{63}$. Zrównoważona relacja EK-O (O autonomizuje się wobec $\mathrm{S}$ ): w zależności od przypadkowych czynników wyłania się rząd parlamentarny (Węgry) lub z tendencją do półprezydenckiego (Polska); proporcjonalna ordynacja w wyborach parlamentarnych.

TD2 - rozpad ZSRR prowadzi do wyzwolenia państw okupowanych od II wojny światowej przez Moskwę - Litwy, Łotwy i Estonii ${ }^{64}$. Społeczeństwa o silnym poczuciu narodowej tożsamości szybko wyłaniają narodowe elity $(\mathrm{O})$, usuwają władze narzucone przez Moskwę i przejmują rządy. Źródłem rekrutacji tych elit były organizacje pozarządowe, kulturalne i ekologiczne ${ }^{65}$. Podobnie aksamitna rewolucja w Pradze wymiotła całą elitę osadzoną tam w 1968 r. przez wojska Paktu Warszawskiego. S/O silniejsze od EK: ponieważ EK kontroluje administrację, O ustanawia rządy parlamentarne dla przejęcia kontroli nad państwem; ordynacja proporcjonalna w wyborach parlamentarnych.

TA - przy słabym społeczeństwie obywatelskim, EK kontroluje w pełni proces zmiany ustroju, ustawiając się w pozycji „partii reformy” i szukając legitymizacji w ideologii nacjonalistycznej lub w hasłach socjaldemokratycznych. Każdy z tych wyborów miał inne skutki, choć oba prowadziły do rządów autorytarnych. Wybór ideologii socjaldemokratycznej (Chorwacja) nie zamykał drogi do przekształceń liberalno-demokratycznych. Wybór ideologii nacjonalistycznej zamykał społeczeństwo w ramach ustroju autorytarnego np. Rosja, Białoruś, państwa Azji Środkowej. EK silniejszy od S/O: EK wzmacnia egzekutywę kosztem parlamentu, lokując demokratyczną reprezentację społeczeństwa w zmarginalizowanym parlamencie; rządy prezydenckie, ordynacja wyborcza większościowa lub mieszana.

Trajektorie TD1 i TD2 prowadzą do konsolidacji ustroju liberalno-konstytucyjnego i można je traktować łącznie, jako transformację ku demokracji - TD; trajektoria TA daje w wyniku różne formy ustroju autorytarnego. Niektóre z państw zmieniły trajektorię TA na TD - Serbia, Słowacja, Bułgaria. Powyższy model jest uproszczeniem i nie pokrywa różnorodności rzeczywistych zjawisk, ale daje szansę wyjaśnienia części problemów związanych z transformacją w kierunku konstytucjonalno-liberalnym.

${ }^{6}$ Zob. G. O’Donnell, Ph. C. Schmitter, Transitions from Authoritarian Rule: Tentative Conclusions about Uncertain Democracies, The Johns Hopkins Univ. Press, Baltimore-London 1986, s. 77-39.

${ }^{63}$ Tylko częściowo przyjmujemy stanowisko V. Bunce (Rethinking recent democratization. Lessons from the postcommunist experience, „World Politics” 55(2), 2003) i M. McFaula (The fourth wave of democracy and dictatorship: noncooperative transitions in the postcommunist world, w: M. McFaul, K. Stoner-Weiss (eds.), After the Collapse of Communism: Comparative Lessons of Transition, Cambridge Univ. Press, Cambridge-New York 2004), którzy traktują wszystkie pokomunistyczne przejścia do demokracji jako niekooperatywne (non-collaborative). W przypadku Polski i Węgier mieliśmy do czynienia z porozumieniem między „reformatorskim” odłamem EK a częścią O.

${ }^{64}$ Casus Litwy z różnych względów zbliżony jest do modelu TD1, inaczej jest w pozostałych krajach.

${ }^{65}$ A. Lieven, The Baltic Revolution. Estonia, Latvia, Lithuania and the Path to Independence, Yale Univ. Press, New Haven-London 1993, s. 220. 
Czynnikiem zewnętrznym silnie wpływającym na procesy transformacji jest geopolityka. Europa jest podzielona między dwa bieguny grawitacji, z których każdy oddziałuje w inny sposób i inaczej ukierunkowuje zmiany ustrojowe. „Bliskość Brukseli” (oddziaływanie UE) sprzyja trajektorii TD, „bliskość Moskwy”, wpływ Federacji Rosyjskiej (FR) - sprzyja TA ${ }^{66}$. „Zachód” wspiera TD za pomoca pozytywnych zachęt - pomocy finansowej, doradztwa i wsparcia politycznego. UE i USA nie wpływały bezpośrednio na wstępną decyzję o liberalizacji, ale na następnym etapie ich wpływ na kształt instytucji wspierających rynki konkurencyjne oraz przemiany demokratyczne był rozstrzygajacy (np. przez acquis communautaire). Po drugie, skłoniły one te kraje do otwarcia rynków na konkurencję innych gospodarek UE i usunięcia ograniczeń na bezpośrednie inwestycje zagraniczne. Otwarcie na świat zewnętrzny przyczyniło się do modernizacji sektorów wytwórczego i usług i korzystnie wpłynęło na jakość zarządzania gospodarką i ograniczenie poziomu korupcji ${ }^{67}$. Warto wreszcie dodać, że „bliskość Brukseli” ułatwiła usunięcie historycznych przeszkód we współpracy między narodami Europy Środkowej i Wschodniej.

„Bliskość Moskwy” działa w kierunku przeciwnym - faworyzuje łatwo podlegajace kontroli, słabe rządy autorytarne. Zmiany demokratyczne w krajach b. ZSRR Moskwa traktuje jako bezpośrednie zagrożenie dla swej racji stanu. FR realizuje wpływ przez uzależnienie gospodarcze, działania agenturalne i groźbę agresji militarnej. Uzależnienie gospodarcze pozwala na szantaż paliwowy (gaz, nafta) lub zamknięcie własnego rynku dla eksportu z danego kraju. Moskwa do destabilizacji sąsiednich państw używa też podległych enklaw (Naddniestrze, Abchazja i Osetia Płd., Krym, Donieck i Ługańsk). Umożliwia to „dyfuzję autorytaryzmu” $\mathrm{z}$ jego rosyjskiego epicentrum ${ }^{68}$.

Podjęte na początku transformacji wybory ustrojowe mają długofalowe skutki dla jakości rządzenia. Do oceny ich wpływu na rozwój ustroju politycznego użyliśmy dwóch miar stosowanych przez Bank Światowy w badaniach jakości rządzenia w ponad dwustu państwach - „uczestnictwo i rozliczalność” (voice and accountability) i „rządy prawa”. Za pomoca tych miar stworzyliśmy zagregowany indeks ustroju politycznego (ZIUP) (tab. 2). Arbitralnie ustaliliśmy granicę kategorii państw demokratycznych na poziomie $55 \%$, tj. dane państwo osiaga na tej skali wynik „lepszy” niż 55\% pozostałych. Trzynaście nowych państw członków UE spełnia ten warunek, a Gruzja i Serbia są tego bliskie. Wartości ZIUP dla Ukrainy i Armenii plasują te kraje między grupa pośrednią a autorytarną: nawet z perspektywy 2016 r. nie jest jasne, w jakim kierunku pójdzie zmiana ustroju politycznego.

${ }^{66}$ A. Z. Kamiński, B. Kamiński, Bezpieczeństwo Polski i regionu w podzielonej Europie, „Sprawy Międzynarodowe” 4(LXV), 2012, s. 21-25.

${ }^{67}$ B. Kamiński, The 'EU Factor' in transition: credibility of commitment, institutional change and integration, w: S. Antohi, V. Tismaneanu (eds.), Between Past and Future: The Revolutions of 1989 and the Struggle for Democracy in Central and Eastern Europe, Central European Univ. Press, Budapest 2000.

${ }^{68}$ Max Bader (Democracy promotion and authoritarian diffusion: the foreign origins of postsoviet election laws, „Europe-Asia Studies” 66(8), 2014, s. 1350-1370) przedstawia bogaty materiał dokumentujący emanujaccą z Rosji „dyfuzję autorytaryzmu”. Wskazuje na wzór prawa wyborczego w Rosji jako źródło niskiej jakości praw wyborczych w państwach pozostających pod jej wpływem. 


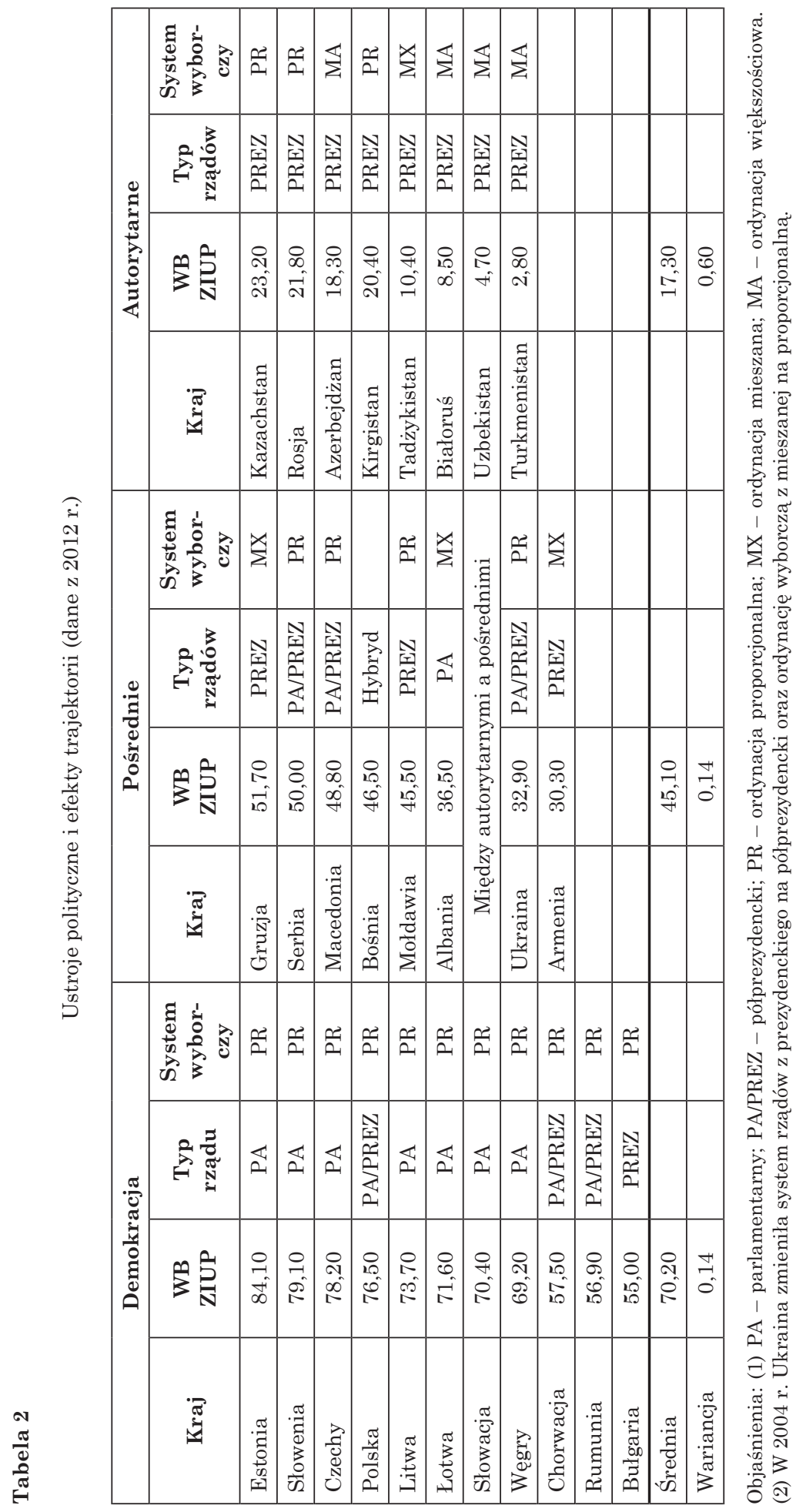


Porównanie wartości ZIUP z dwoma z podstawowych wyborów konstytucyjnych, typem rządu oraz ordynacji wyborczej, pozwala stwierdzić, że wszystkie państwa autorytarne maja, formalnie rzecz biorąc, rządy prezydenckie, wszystkie państwa zaliczone do demokratycznych mają ordynację proporcjonalna. Państwa autorytarne mają zróżnicowane ordynacje wyborcze, co nie ma znaczenia, zważywszy, że „prawo wyborcze” z góry faworyzowało elity rządzące ${ }^{69}$.

Z pewnością elity polityczne optujące za proporcjonalnym systemem wyborczym nie kierowały się zasadą sprawiedliwości społecznej; te zaś, które optowały za systemem większościowym, nie robiły tego z uwagi na skuteczność i rozliczalność rządów. Decyzje w kwestii formy rządów też nie miały związku z opiniami Juana Linza. Sprawy te rozstrzygano pod wpływem dominujacych interesów i kalkulacji ich efektów ${ }^{70}$. Spójrzmy na te wybory z punktu widzenia relacji EK-S-O, tj. układu interesów zakorzenionego w komunistycznych instytucjach ustrojowych EK, społeczeństwa S oraz wyniesionego przez S nowego układu interesów $\mathrm{O}$.

Kryzysom politycznym towarzyszy dezintegracja klasy rządzącej. Rozkład klasy rządzącej jest wstępem do zmiany ustroju. Jest to też warunek konieczny, by społeczeństwo, jako zbiorowość, mogło wejść na scenę wydarzeń. Następnym krokiem umożliwiającym wyjście poza etap rebelii jest organizacja. W Polsce był to NSZZ „Solidarność”. Organizacja musi mieć przywódców i aparat. Z tą chwilą społeczeństwo zyskuje reprezentację, której siła wobec totalitarnego państwa zależy od jego społecznego poparcia. Przywódcy O stanowia koalicję, a nie jednorodną zbiorowość, łączą się w sytuacji zagrożenia, lecz każda jednostka i grupa ma własne interesy i ambicje. Rząd komunistyczny może wpływać na relacje w O, wspierajacc subtelnie jedne kosztem innych. Rozpoczęcie nieformalnych rozmów, a następnie formalnych negocjacji między EK i O rozluźnia bliską więź między S i O. Przywódcy $\mathrm{O}$ mogą zawrzeć kompromisy trudne do przyjęcia dla społeczeństwa; przedstawiciele EK znajdują się w podobnej sytuacji wobec aparatu. Obie strony muszą ukrywać część informacji, manipulować, a także wprowadzać w błąd swoich popleczników. S staje się źródłem niepewności, a nawet zagrożeniem dla O: nić wzajemnego zaufania zostaje osłabiona. Szczególnie gdy w wyniku ugody dotychczasowi opozycjoniści zajęli pozycje władzy i przywileju, których nie chcą utracić. Niezależnie od trajektorii nowa elita władzy stara się tak ukształtować nowy ustrój, by zapewnić sobie trwałość dostępu do władzy i przywileju ${ }^{71}$. W tej sytuacji ordynacja proporcjonalna, która ogranicza zdolność elektoratu do rozliczenia rzadów, jest dla elity politycznej korzystna, gdyż osłabia kontrolę elektoratu nad rządem. Ten problem występuje głównie przy TD1, kategoria TD2 obejmuje bowiem byłe republiki ZSRR o znacznym udziale mniejszości rosyjskiej. Wobec kombinacji zagrożenia zewnętrznego i wewnętrznego elity musiały szukać

69 Ibidem.

${ }^{70}$ G. O’Donnell, Ph. C. Schmitter, op. cit., s. 4-7; J. Zakrzewska, Spór o konstytucję, Wyd. Sejmowe, Warszawa 1993; V. Bunce, op. cit., s. 170-174.

71 J. Pope, Confronting Corruption: The Elements of a National Integrity System, Transparency International, Berlin 2000, s. 131-132. 
oparcia i współdziałania w narodowej większości, neutralizując opór mniejszości rosyjskiej - zatem musiały dążyć do wzmocnienia narodowego S.

Rzecz wygląda inaczej w Rosji, która w bloku komunistycznym pełniła funkcję metropolii. Sytuacja w ZSRR różniła się od Chin, gdzie po śmierci ojca założyciela, Mao Tse-tunga, przystapiono do urynkowienia gospodarki, co skierowało kraj na droge szybkiego wzrostu gospodarki i poprawy dobrobytu ludności w warunkach istniejaccego ustroju politycznego. ZSRR znalazł się w latach osiemdziesiątych w głębokim kryzysie gospodarczo-politycznym. Próby wyjścia z niego zakończył rozpad państwa. Jeżeli pominać trzy republiki bałtyckie, w pozostałych wyrosłych z niego państwach kontrola nad procesem zmiany ustroju pozostała w ręku establishmentu komunistycznego - EK. Osiagnięto to, skupiając władzę wykonawczą w urzędzie prezydenckim i rozładowując napięcia społeczne, przejściowo liberalizując życie publiczne i dopuszczając quasi-wolne wybory. Pozwoliło to zachować pozory demokratyzacji. Preferowano mieszany system wyborczy. Jak zauważył Andrew Wilson, ordynacja proporcjonalna pozwoliła zaistnieć centralnie kontrolowanym partiom, system większościowy zaś umożliwił użycie prymitywnych form nacisku administracyjnego ${ }^{72}$. Prywatyzacja gospodarcza polegała na przekazaniu znacznej części sektora państwowego w ręce ludzi EK, co dodatkowo zintegrowało klasę rządząca, jako „właścicieli państwa”.

Rosjanie widzieli w ZSRR wyraz narodowych aspiracji i rękojmię statusu supermocarstwa. Ich stosunek do ustroju komunistycznego był więc odmienny od narodów, które w wyniku wojny utraciły suwerenność. Postawy innych narodów wobec reżimu cechowało odrzucenie; w najlepszym razie - obojętność. Upadek komunizmu spowodował u Rosjan poczucie narodowej klęski. Nacjonalizm, w rosyjskiej formie, utrudnił przemiany demokratyczne w Rosji. Drugą przeszkodą było bogactwo zasobów mineralnych - wzrost cen ropy i gazu pozwolił nowej elicie „wykupić się” z konieczności reformy gospodarczej. Rosja, kraj o wysoko wykwalifikowanej sile roboczej i rozwiniętej bazie naukowo-technicznej, ma strukturę gospodarczą typową dla krajów o znacznie niższym poziomie rozwoju. Wykorzystanie bogactw naturalnych w polityce wewnętrznej, a także w polityce zewnętrznej dało efekt w postaci „przekleństwa zasobów mineralnych"73 i doprowadziło do centralizacji rządów autorytarnych. W rezultacie rząd uniezależnia się od wolnorynkowego sektora prywatnej przedsiębiorczości, a jego priorytetem staje się kontrola nad strumieniem środków generowanym przez sektor surowców energetycznych. Zwalnia to rządzących od troski o rozwój infrastruktury instytucjonalnej, chroniącej własność prywatna i pobudzającej procesy rozwojowe w gospodarce. Elita polityczna państw tej kategorii stała się niewolnikiem inercyjnej, zależnej od zewnętrznego popytu, struktury gospodarczej ${ }^{74}$.

72 A. Wilson, Virtual Politics: Faking Democracy in the Post-Soviet World, Yale Univ. Press, London-New Haven 2005, s. 87.

${ }^{73}$ R. M. Auty, Sustaining Development in Mineral Economies: The Resource Curse Thesis, Routledge, London 1993; J. D. Sachs, A. M. Warner, Natural Resource Abundance and Economic Growth, NBER Working Paper 5398, 1995.

${ }^{74}$ Przegląd literatury wykracza poza ramy tego artykułu. Zamiast tego polecamy syntetyczne omówienie wyników badań naukowych nad związkami między warunkami gospodarczymi a de- 


\section{UWAGI PODSUMOWUJĄCE}

Przedmiotem badań prowadzonych przez politologów i ekonomistów politycznych zajmujących się konstytucjonalizmem są efekty przyjętych w poszczególnych państwach rozwiązań ustrojowych. Badania prowadzone są za pomocą statystycznych analiz porównawczych. W pierwszej części artykułu przedstawiliśmy w ogólnym zarysie podstawowe wybory ustrojowe wchodzace w zakres zainteresowań badaczy tego kręgu. Nacisk położyliśmy na postawy ideowe elity politycznej, tj. osób i środowisk, które decydują w kwestiach konstytucyjnych, oraz na stan społeczeństwa obywatelskiego. Czynniki te maja szczególne znaczenie w okresach zmian ustrojowych, kiedy szczególnie licza się preferencje „projektantów ustrojowych”, tj. osób decydujaccych o treści wyborów oraz o kondycji społeczeństwa, jako siły będącej w stanie, lub nie, pełnić rolę ograniczającą arbitralność tych wyborów.

Wybory ustrojowe traktujemy tu jako grę o rozliczalność między nową elitą władzy nastawioną na realizację waskko partykularnych interesów a społeczeństwem obywatelskim. Przedstawione wyniki odbiegają od tego, czego można byłoby się spodziewać na gruncie istniejącego stanu wiedzy w politologii i konstytucjonalnej ekonomii politycznej: połączenie rządów prezydenckich i ordynacji większościowej w sytuacji transformacji pokomunistycznych jest rozwiązaniem najgorszym i prowadzi do rządów autorytarnych (zob. tab. 2). Nie sposób jednak uznać dokonanych przez te kraje wyborów i ich skutków za wnoszące cokolwiek do debat omówionych w pierwszej części artykułu. Poza jednym: czynnikiem rozstrzygającym o jakości rządów jest stan społeczeństwa obywatelskiego.

W grze o rozliczalność elity transformacyjne działaja zgodnie ze swym partykularnym interesem, z jednej strony próbując rozszerzyć zakres swobody $\mathrm{w}$ stosunku do establishmentu komunistycznego, z drugiej - optując za rozwiązaniami instytucjonalnymi ograniczającymi zdolność społeczeństwa obywatelskiego do rozliczania ich z efektów ich działań. W rozważanych tu procesach przemian ustrojowych wystapiły dwa rodzaje przypadków: 1) kombinacja partykularystycznej elity ze słabym, niezdolnym do obywatelskiego współdziałania społeczeństwem; 2) kombinacja partykularystycznej elity ze zdolnym do ograniczonej samoorganizacji społeczeństwem obywatelskim. Pierwszy dał w wyniku rozstrzygnięcia konstytucyjne majace za podstawę rządy prezydenckie wraz z ordynacją większościową lub mieszaną proporcjonalna w wyborach parlamentarnych. Prowadziło to we wszystkich przypadkach do ustroju autorytarnego. Druga droga prowadzi do konstytucyjnego liberalizmu. Cechuja ją rządy parlamentarne i ordynacja proporcjonalna. Jej podkategorią sa państwa, gdzie mieliśmy do czynienia z „paktem transformacyjnym”, tj. Polska i Węgry. Niepewność związana z działaniami społeczeństwa obywatelskiego spowodowała tu milczące porozumienie części antykomunistycznej opozycji z częścią sił starego reżimu, mające na celu demobilizację społeczną.

mokratyzacją: N. Bandeli, B. Radu, Consolidation of democracy in postcommunist Europe, Paper 0604, Center for the Study of Democracy, Univ. of California, Irvine 2006. 
W Polsce szczególnie podporządkowane temu było przeciaganie w czasie procesu konstytucyjnego, a także same wybory ustrojowe ${ }^{75}$. W obu przypadkach doprowadziło to do niestabilnego porządku konstytucyjnego.

Niezależnie od wewnętrznego układu sił, wpływ na treść wyborów ustrojowych miał czynnik zewnętrzny - bliskość EWG/UE vs. bliskość Federacji Rosyjskiej. Wszystkie kraje „blisko Brukseli” wybrały trajektorię prowadząca do ustroju konstytucjonalno-liberalnego; wszystkie państwa „blisko Moskwy” wybrały system autorytarny. Potwierdza to w pewnym stopniu tezy Feliksa Konecznego ${ }^{76}$ i Samuela Huntingtona ${ }^{77}$ o dwoistości cywilizacji europejskich: łacińskiej i bizantyjskiej.

prof. dr hab. Antoni Z. Kamiński

Instytut Studiów Politycznych Polskiej Akademii Nauk

$w$ Warszawie

kaminski@isppan.waw.pl

prof. dr hab. Barttomiej Kamiński

Uniwersytet Marylandu w College Park

oraz Wyższa Szkoła Informatyki i Zarzqdzania w Rzeszowie

bkaminski@umd.edu

\section{CONSTITUTIONAL ENGINEERING IN TRANSITIONS FROM COMMUNISM}

Sum mary

While there is a wealth of studies on selected aspects of economic and political transitions from communism, there are few, if any, analyses of the emergence of new political orders in terms of constitutional engineering, i.e. the adoption of the meta-rules governing the rules defining both the political structure and determining underpinnings of the ordinary law-making process. The paper begins with the review of menu of institutional choices related to type of government, electoral system and vertical organisation of the state and their impact on performance as reported in political science and constitutional political economy literature. It is posited that the binary outcome: democracy vs. autocracy is a function of two variables assuming two values: society (weak vs. autonomous sovereign citizen) and communist establishment (strong vs. weak). A strong communist state at the initial state of transition produces autocratic outcomes although proximity to Brussels may change political trajectory whereas a strong autonomous society generates trajectory leading to democracy. Surprisingly, the choice of the rules of political game bore little resemblance to what literature might suggest: ordinary political struggle has determined the choice of institutions with constitutions as a legal act being the result rather than a product of conscientious intellectual design.

JEL: A10; A12; B25; P10; P20; P21; P30

${ }^{75}$ A. Z. Kamiński, Dezercja elit. Konsolidacja ustroju politycznego w pokomunistycznej Polsce, ISP PAN, Warszawa 2014.

${ }^{76}$ F. Koneczny, Cywilizacja bizantyńska, Wyd. Tow. im. R. Dmowskiego, Londyn 1973.

${ }^{77}$ S. Huntington, Zderzenie cywilizacji i nowy kształt tadu światowego, tłum. H. Jankowska, Warszawa 2004. 